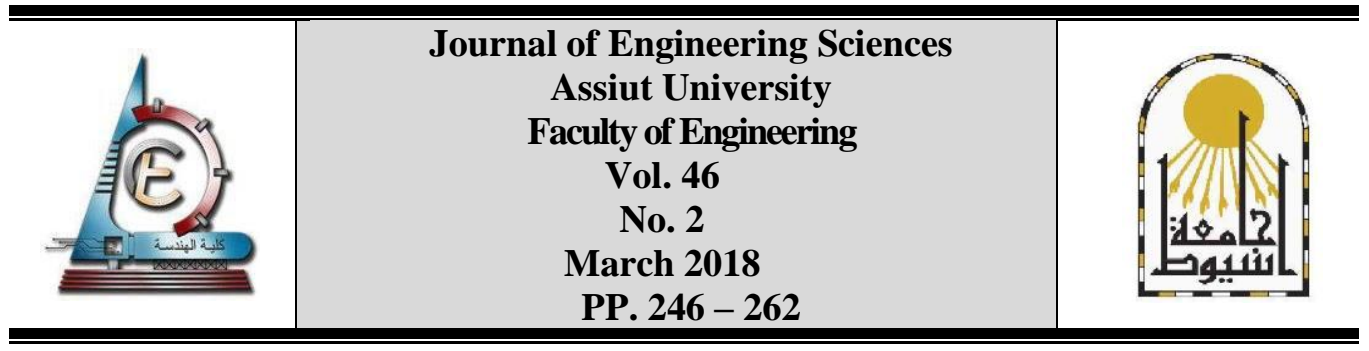

\title{
VERTICAL GARDEN AS A SUSTAINBLE URBAN PRESPECTIVE IN CAIRO
}

\section{Reham Ibrahim Momtaz}

\author{
Architecture Engineering, Modern Academy, Cairo, Egypt
}

Received 24 January 2018; Accepted 1 February 2018

\begin{abstract}
Egypt is experiencing a rapid economic growth, developments in urban areas in addition to shrinking in green area and that leads to the occurrence of environmental problems such as drought, pollutants and the phenomenon of heat island in the urban areas. This paper therefore focuses on the benefits and techniques of the vertical gardens as a solution of environmental problems in Cairo as the vertical gardens may contribute in significant environmental, social and economic benefits in the urban environment with high population density.
\end{abstract}

Moreover, the paper highlights on the examples of architectural buildings integrated with vertical gardens as new urban perspectives to face climate change and the energy crisis.

The paper aims to provide a checklist for vertical gardens design as an evidence of future efforts to implement the strategy of the vertical greening garden in Cairo. Moreover, this paper discusses the prior knowledge of the residents towards the phenomena of the green wall and the factors which affected its implementation.

Finally, the paper is concluding with a checklist of design considerations for vertical garden and several recommendations for using vertical garden technique as an alternative innovative technology to sustainable urban development which fits the urban structure in Cairo.

Keywords: Vertical Garden, Green Wall, Green façade, Vertical Garden systems, energy saving

\section{Introduction}

Throughout history the greening of outside walls and roofs of buildings has taken place. Reasons for doing so were the increase of insulation (keep cool in summer and keep cold out in winter), improved aesthetics, improved indoor and outdoor climate, reduce the greenhouse gases such as Carbon Dioxide (CO2), Carbon Monoxide (CO) and Nitrogen Dioxide (NO2) as well as increasing ecological values by creating habitats for birds and insects. [1].

Over the years, replacement of vegetated surfaces with impervious surfaces in urban areas has resulted in the increase in temperature compared to the surrounding rural areas. Since the paved surfaces absorb, retain, and reradiate more solar energy than grasses and trees. The ambient temperature in urban area could be $6^{\circ} \mathrm{C}$ warmer than the air in rural areas [2].

Vertical Garden is essential for the improvement of the built environment's sustainability. Their implementation is also ecologically and aesthetically acceptable as an adequate architectural feature that upgrades facades. Moreover their exploitation leads to 
an energy conscious design which prevents densely populated urban areas in Cairo from transforming into a deteriorated natural environment [3].

\section{The vertical garden}

The term Vertical Garden or vegetated façade has defined as a system which plants is grown on vertical surfaces such as a building facades and walls in an organized manner and systematic upkeep. Climbing plants are growing naturally on building facades by attaching themselves directly to vertical surfaces using several techniques. Self climbing climbers and self-supporting woody plants can attach themselves directly to the facade surface or grow along the facade without any support. The main item of green walls are plants, plants media, structures that support and attach plants to facade and the irrigation system that relies on the design [4]

The maintenance is an important factor which should be discussed with the client before choosing the design of the facades to define the design criteria, the selection of plants and the type of vertical garden. Maintenance falls into a number of categories [5]:

- Establishment maintenance occurs during the first one to two years after installation. For vegetation, this includes tasks such as pruning, weed control, and irrigation to ensure healthy and vigorous plant growth.

- Recurrent maintenance for facades include standard of appearance, functionality and safety. For vegetation, includes tasks such as weeding, pruning, removal of leaf litter and, in some cases, mowing.

- Cyclic maintenance includes maintenance of the underlying building structure and of specific components of the green wall system.

Vertical gardens have many potentials and opportunities already visible, not only as an active contribution to environmental and Nature, but also, have main role to promote human Health [6].

\subsection{Main types of green vertical garden}

Many criteria could be used to define different kinds of vertical gardens, according to the characteristics and development of plants, the type of growth substrates and the constructive system.

\subsubsection{Green façade}

The green facade wall is a kind of vertical garden system as the climbing plants grow on buildings [2]. As a mean of the plants to grow, the soil is put on the bottom of the wall or sometimes at the top. This method can takes from 3 to 5 years for the plants to fully grow and then to cover the whole facade. The common kind of climbing plants that are used in this system is the English Ivy. However, there is a problem when using this type of plant. The strong root of an English Ivy will cause the damage of the structure and become more difficult to remove it from the facade later.

Generally is used drip irrigation utilizing emission devices at the base of every plant or incorporated into a surrounding sprinkler system.

Technological innovations have resulted in the development of new trellises, rigid panels and cable systems to support vines, while keeping them away from walls and other building surfaces. Two green facade systems that are often utilized are modular trellis panel and cable and wire-rope net systems. Each of these systems is described below:

- Modular Trellis Panel System 
The building block of this modular system is a solid, light weight, three-dimensional panel made from a powder coated galvanized and welded steel wire that supports plants with two faces grid and a panel depth [7]. This system is designed for holding a green facade off the wall surface so that plant substances don't append to the building, provides a "captive "growing environment for the plant with multiple supports for the tendrils, and aids in maintaining the integrity of a building membrane as shown in [Figure-1]. Panels can be stacked and joined to cover large regions, or formed to create shapes and curves are made from recycled content steel. Because the panels are solid, they can span between structures and can also be used for freestanding green walls [8]. Irrigation is usually built-in and placed on automatic timers. This system may be susceptible to wet and dry areas and needs to be monitored. It is generally the least expensive option, costing 1000-1500 EGP / $\mathrm{M}^{2}$ installed.

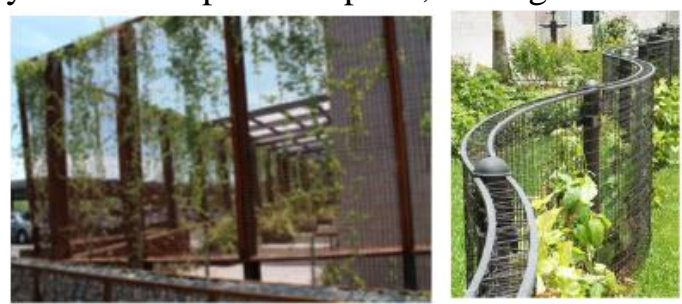

Fig. 1. Modular Trellis Panel System [8]

- Cable and Wire-Rope Net Systems

The cable and wire-rope net systems use the cables and a wire-net. Cables are worked on green facades that are designed to support the rapid growing of climbing plants in a more intense manner. Wire-nets are more flexible and provide a greater level of design applications than cables. Both systems use high tensile steel cables, anchors and supplementary equipment as shown in [Figure-2]. Various sizes and patterns can be received as flexible vertical and horizontal wire-ropes are connected through cross clamps $[7,10,11]$ this is generally a less expensive option, costing 1500-2000 EGP / $\mathrm{M}^{2}$ installed.
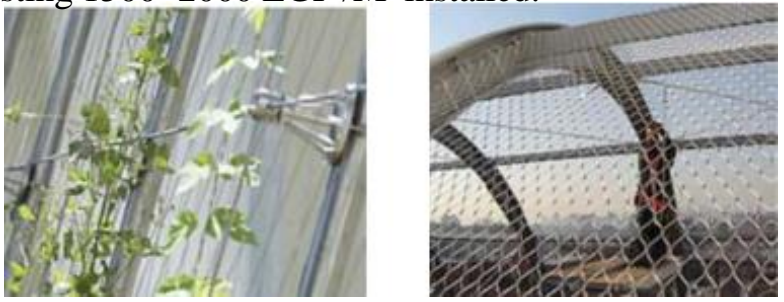

Fig. 2.Cable and Wire (left) Rope Net Systems (right) [8]

\subsubsection{Living walls}

The living walls are composed of more than one kind of plants. Using this method, groundcover plants are made possible to be planted vertically on the wall surface. It is made up of planted or vegetated unit's structures that are of plastics, metal, or other materials that are connected vertically to a structural cadre. This kind of the vertical garden usually needs more care and maintenance compared to the others as it has to support a great scope of plant species. The system of living walls is different according to the design and functions [12]

- Modular living walls (Green screen)

A modular living wall is inspired by the system of a green roof that uses units as a mean to support the growth of plants. 
This system, the plant is supported by multiples panels that are of square and rectangular shapes in [Figure-3]. Each panel composed of growing medium that contains different soil and nutrients composition depending on the types of plant used. The irrigation type for this system is usually placed on top of the units in order to distribute the water through the growing media using gravity pulls [12]. Costs can be higher, generally ranging from 2000-3500 EGP / $\mathrm{M}^{2}$ installed.
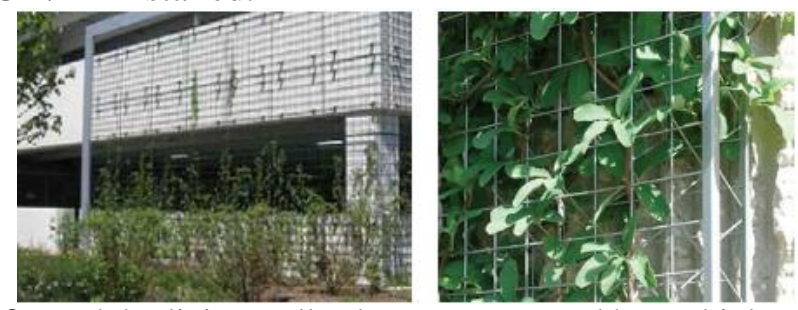

Fig. 3. Modular living walls plant are supported by multiples panels [9]

- Vegetated mat wall

The 'Mur Vegetal' is a rare form of green facade system that is designed by the French botanist, Patrick Blanc as shown in [Figure-4]. In this system, the plant is supported by two layers of synthetic fabric with pockets. This fabric walls are later associated with a greater frame located on top of the wall surface layered with waterproof membrane to prevent from any damage to the existing wall due to its high moisture content. The irrigation system is usually built into the wall and plants are irrigated from the top of the wall, with a catch basin to capture the water below. In some systems this captured water can be re-circulated back into the irrigation system [13]. These walls are the most expensive and generally range from 5000-6000 EGP $/ \mathrm{M}^{2}$ installed.
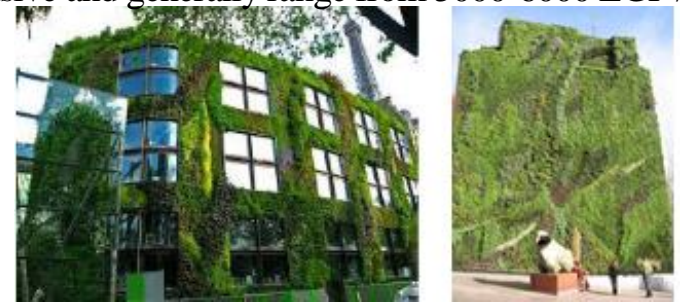

Fig. 4. The famous 'Mur Vegetal' designed by Patrick Blanc [14]

\subsection{Benefits of green facades and living walls}

There are important benefits to both the public and private strips resulting from the successful use of green walls. Green walls have a great potential for positive environmental change in dense urban areas, particularly given the large surface areas on buildings that are available for retrofitting to these technologies [15].

\subsubsection{Environmental benefits}

- Increasing energy efficiency in buildings

Green wall technology helps buildings become more energy sufficient and helps to reduce the urban heat island effect, absorb storm-water, and leads to reduced carbon emissions in [Figure-5]. It plays the role of protective barrier which provides better solar protections that can reduce the effect of the external load and the cooling need [16]. Previous observations indicated that green walls reduce the heat gain, and their surface temperature is lower than an exposed wall. 


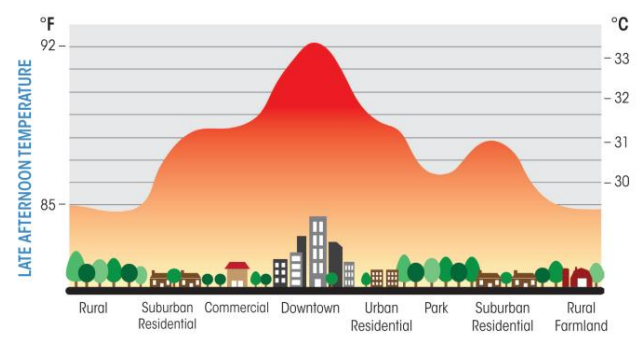

Fig. 5. Urban Heat Island effect profile

Based on the analysis studies, the external surface of a green wall is up to $10^{\circ} \mathrm{C}$ cooler than an exposed wall; therefore the U-value for the green wall is usually lower and helps to reduce cooling loads. Previous studies demonstrated that non-vegetated areas could exceed temperatures of $50^{\circ} \mathrm{C}$ in July while vegetated areas remained at $25^{\circ} \mathrm{C}$ [17]. In winter, green wall techniques act as insulation layer by moving air between the plant and the wall and creating a buffer against the wind which reduces cool air coming in. The level of energy saving depends on many factors such as climate, building skin type, and density of plant coverage [18].

- Sound insulation

In urban environments, plants and trees have been used as baffles against urban noise pollution. Plants, soil, and the trapped layer of air can absorb, reflect or deflect sound waves. So, green walls have a strong insulation that is better than (up to $30 \mathrm{db}$ ) than that of exposed wall, as shown in [Figure-6-] [19].The degree of sound insulation provided by the green wall depends mainly on elements that affect noise reductions including depth of the growing media, type of plants, and the materials used for the structural components of the living wall system, and the layer of air between the plants and the wall. In terms of sound control, the option of the suitable type of green wall technique depends mainly on the site conditions, climate conditions, and the function of the inner space [20,21].

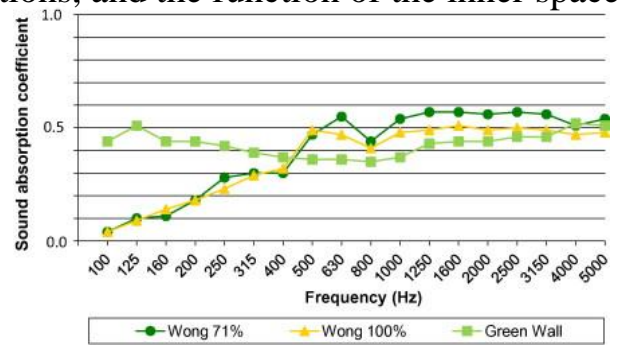

Fig. 6. Sound absorption coefficient value comparison results between Ordinary wall and the vertical garden [21]

\subsubsection{Community and social benefits}

\section{- Aesthetic Influences}

The utilization of vertical garden is a highly influenced method of transforming the urban landscape [22], through using advanced materials and technology to promote sustainable urban development [23]. Creative role of vertical garden as architectural solution to transform implement greenery factors for the restoration of old buildings definitely contribute in improvement the esthetical aspect of our cities [24].

Based on performed studies to evaluate the esthetic influence and the level of perceived restoration that may be performed by putting green facades onto building, integrated green walls 
with Buildings were more preferred and considered more beautiful, esthetically pleasing, and restorative than those without vegetation. In addition, the importance of an adequate selection of plant species in the implementation of a green wall from the esthetic point of view. [25, 26, 27].

- Social Implications

Living in urban environments, where surrounded by concrete, traffic, noise and pollution therefore has a profound negative impact on our physical and mental wellness. Greenery softens this hard environment, through provides a substantial and spiritual connection to nature that missing in the current city [28].

According to scientific Studies, Simply having a view of greenery reduces symptoms stress and gives positive physiological responses .In addition, Plants promote human health and wellbeing, which lead to an increase in productivity and creativity [29].

\subsubsection{Economics benefits}

The return on vertical garden investment may not seem obvious at first. But in fact, Economics benefits are associated with the environmental benefits of the vertical gardens [30]. to discover the economic benefits of vertical gardens through the utilization of Plants around buildings that, reduce the climatic stress, Protect the construction integrity which, lead to Longevity of buildings. Furthermore, the utilization of vertical garden can reduce environmental effects on building façades therefore, which decreases energy consumption [31].

\subsubsection{Utilizing vertical garden in a sustainable context}

Prospective development refers to a socio-ecological operation distinguished by the fulfillment of human needs while maintaining the quality of the natural environment. Prospective development could be performed by architects, town planners, engineers and manufacturers of building products working cooperatively to produce green buildings that are designed, built, or operated in an ecological way [32]. Green Architecture is an approach that assures the place of buildings within both local ecosystems and the global environment. Utilizing vertical garden is the practice of increasing energy efficiency, and reducing building effect on human health and the environment [33].

Therefore, Contribution of vertical garden technology in existing buildings and new ones improves Environmental, economic and social aspects since it covers issues like sustainability, energy saving, air quality, water efficiency, and acoustics and promote human health, wellbeing and satisfaction [34].

\section{Integral vertical greening gardens and buildings}

Architecture and vegetation are fused together, turning the latter into a construction material, keeping the building relevant for an undefined time. The broad range of direct and indirect benefits along with the space availability for their implementation in buildings facades present many reasons to expect that green wall may play a main role as green concepts within forthcoming sustainable urban plans. Indoor air quality could be guaranteed by means of the bio-filtration effect of living walls, while the cooling effect of the current systems would permit lower energy requirements [32, 34].

By this part of the paper, The case studies of redeveloped and new projects are being analyzed to recognize the benefits of integrate vertical greening gardens and buildings as an approach to energy saving and reduction of heat island effect, in addition to other environmental benefits. 


\subsection{Consorcio Santiago offices, Santiago, 1993}

An outstanding example of this new vision for intelligent building envelopes is shown in Consorcio Vida building in Santiago, Chile; one of the main distinguishing characteristics of the project is the use of dynamic shading presented by deciduous vines that grow to almost the full size of the West facade. They were conceived as a "vertical garden", sixteen stories high adding a green region that contributes to improve the environmental quality of the zone as shown in [figure-7] [35].
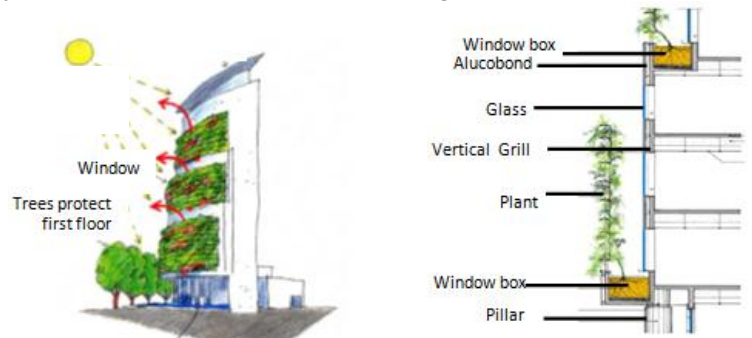

Fig. 7. Concept drawing for the green façade (left) .Detail Vertical Section (right) [33].

Utilizing the green wall on the Western side of the office building presents a gap between the plants and the glass of the office building. The green wall and curtain wall is called a double facade. The double facade allows for hot air to keep the building cool and creates a moisture microclimate in the dry Santiago valley where it is located. The green wall also presents an interesting view for an office [36], as shown in [Figure-8].
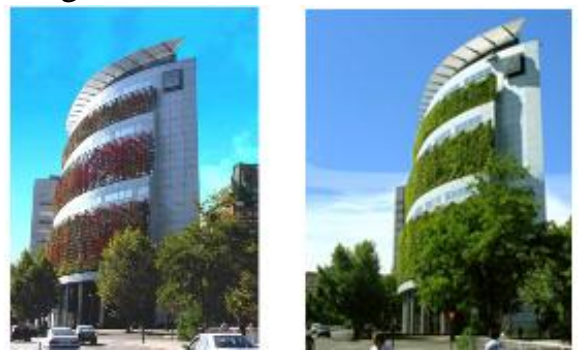

Fig. 8. Colorful facade at autumn (left), Green facade at summer (right) [36]

\subsection{Edith Green-Wendell Wyatt Federal Building, Portland,2013}

It was built in 1975 at 18 stories and established of concrete and glass and the renewing project was completed in 2013. Renewing project depended on the vertical fins to shade the western facade in the spring and summer and in the winter the plants go away and warm the building. Additionally, captured rainwater from the roof and grey water from the interior plumbing are used to irrigate the green facade .Now the building is using 60-65\% less energy than comparable buildings [37-38], as shown in [Figure-9].

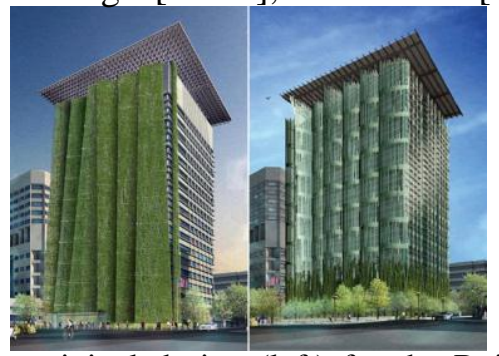

Fig. 9.The living wall in the original design (left) for the Building has been replaced with a system of aluminum rods (right) [38] 


\subsection{The EDITT Tower, Singapore, 1998}

The building façade elements and vegetation were fused together to enhance the indoor air quality, saving energy and improve the environmental quality.Incorporated a vegetation with façade is designed to be continuous and to ramp upwards from the ground plane to the upper most floor by way of a linked landscaped ramp.The area of green façade is $3818 \mathrm{M}^{2}$ So, the plants were selected from indigenous plants to assure that the vegetation be incorporated in the design which would compliment the enviromental view. The green façades' irrigation system depended on grey water. [39], as shown in [Figure-10].
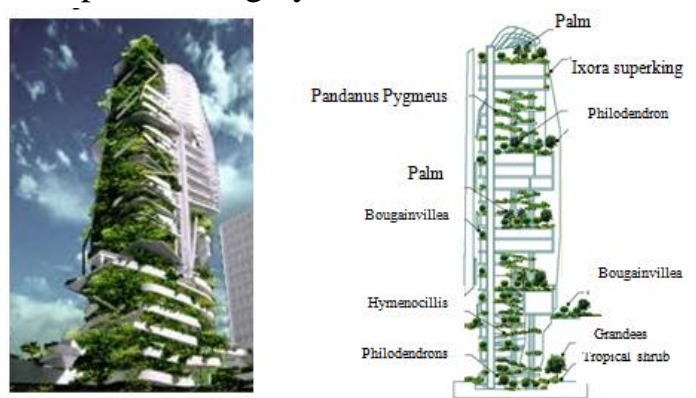

Fig. 10. EDITT Tower (left), The Planting concept (right) [39].

\section{Vertical green garden as a sustainable urban perspective in Cairo}

The paper is presenting an analytical study in three stages:

The first stage consist of a proposed checklist of the design considerations for vertical greening garden which suites the Egyptian Society.

The second stage discusses the citizens' prior knowledge towards vertical garden. Which helps in analyzing the citizens' concerns about the vertical garden and shows the social acceptance towards using green walls on building facades?

The third stage represents the analysis of architects that reflects the importance of each design element for vertical greening garden to achieve sustainable urban perspectives in Cairo.

\subsection{Proposed checklist of design considerations for vertical garden}

The checklist consists of architectural, environmental, economical and construction considerations of vertical gardens.

The paper, through conducting a deep theoretical review, could define checklist of design considerations for vertical greening garden as shown in [Table -1].

Table 1.

Proposed checklist of design considerations for vertical garden [Source - Researcher]

\begin{tabular}{|l|ll|}
\hline Architectural considerations & Environmental considerations \\
\hline Vertical garden types & Reduced energy use \& temp. control \\
\hline Location of façade & Noise reduction via insulation \\
\hline Aesthetic and urban design & Improved indoor air quality & \\
\hline $\begin{array}{l}\text { Green wall is compatible with building } \\
\text { design }\end{array}$ & Adapting to climate change & \\
\hline $\begin{array}{l}\text { Native plant material which adaptable to } \\
\text { local weather conditions }\end{array}$ & $\begin{array}{l}\text { Integrate - landscape, biomass \& } \\
\text { biodiversity }\end{array}$ \\
\hline Determining a plant's hardiness & Reduce urban heat Island \\
\hline
\end{tabular}


Table 1. (Cont.)

\begin{tabular}{|l|l|}
\hline Facade surface area & Improved public health and wellbeing \\
\hline Plant material selection & Planting bed/ soil preparation \\
\hline Economical considerations & construction considerations \\
\hline Irrigation installation costs. & Availability of drainage system \\
\hline Materials cost & Protection to building structure \\
\hline $\begin{array}{l}\text { Installation of the system components, plants } \\
\text { and plant materials }\end{array}$ & Utilizing grey water technology \\
\hline Maintenance expenses & $\begin{array}{l}\text { Green wall is compatible with the type of } \\
\text { construction }\end{array}$ \\
\hline & Irrigation availability \\
\hline
\end{tabular}

\subsection{Methods}

The questionnaires were designed by editing a set of questions which investigate and identify the significance of vertical garden. 60 questionnaires were distributed randomly to residents. In addition, 50 questionnaires' copies were distributed equally to landscape engineers and architects. The researcher had to explain and clarify the questionnaire type every time, but without explaining the purpose of the questionnaire to avoid directing the answers to a certain direction

All questionnaires were unloaded and scheduled manually (uploaded data tables), and then information is entered into computer by using a program for statistical researches "SPSS" to prepare the required statistical operations.

The statistical operations are divided into two basic stages: Descriptive analysis was used to determine the central tendency of the sample, where a variable are collected in the scales. It was used to calculate the values of the different variables of the questionnaire. Standard deviation: It shows the degree of dispersion and distribution of the values of the variables, i.e. the extent of dispersion of these values with respect to a variable, i.e. the degree of proximity or distance among them as well as the frequency through which it shows the number of experts who chose the relative weight of the question between (1-5) as (1) is the lowest relative weight, and (5) is the highest relative weight and (0) is inappropriate.

Component Analysis (Factor Analysis) analysis of architects and landscape engineers' choices on the bases of suggested checklist of design considerations for green wall (variables) to identify the weight and significance of each diversity and to be able to reduce the variables to less ones. If the number is greater than 0.5 , the variable is strong, and if it is less than 0.5 ., the variable is weak.

\section{A. Citizens' Prior Knowledge towards Vertical Garden}

Primary observations in Cairo neighborhoods confirmed preliminary evidence that some vertical garden, such as balcony planting, container system, and direct green screens especially cable system, are a part of Cairo citizens' architectural patterns in [Figure-11].

The main aim of the survey is to discover the citizens prior knowledge about vertical garden. 

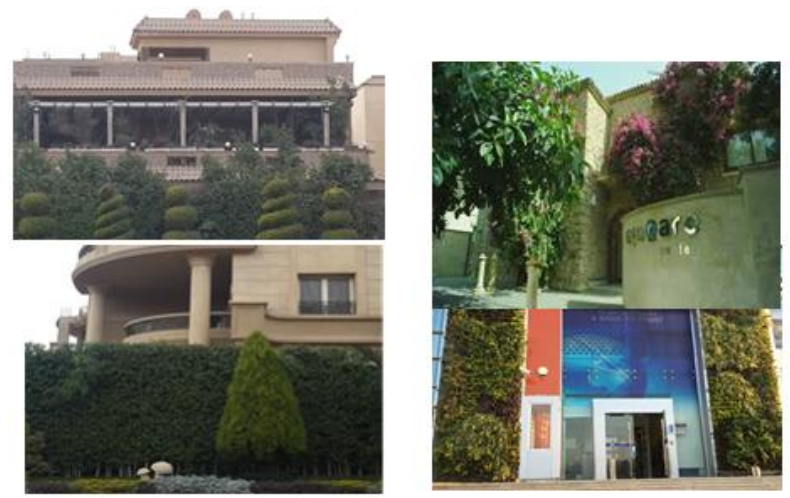

Fig. 11. Randomly selected buildings showing balcony planting, container system, and direct green screens especially cable system. Cairo. [Source - Researcher]

Table 2.

Frequency Distribution of Citizens' Prior Knowledge towards Vertical Garden [Source-Researcher]

\begin{tabular}{|l|l|l|l|}
\hline \multirow{2}{*}{ The benefits of vertical garden } & \multicolumn{3}{|l|}{ Citizens' Prior Knowledge } \\
\cline { 2 - 4 } & Yes & No & $\begin{array}{l}\text { Positive } \\
\text { percentage }\end{array}$ \\
\hline Utilizing green wall & 47 & 13 & $78.33 \%$ \\
\hline Green wall implementation & 39 & 21 & $65 \%$ \\
\hline Aesthetic Influences & 60 & 0 & $100 \%$ \\
\hline promoting human health and wellbeing & 51 & 9 & $85 \%$ \\
\hline Improved indoor air quality & 33 & 27 & $55 \%$ \\
\hline Reducing energy use & 12 & 48 & $20 \%$ \\
\hline Noise reduction & 12 & 48 & $20 \%$ \\
\hline Positive Impact on building envelope & 38 & 22 & $63.33 \%$ \\
\hline Maintenance expenses & 32 & 28 & $53.33 \%$ \\
\hline Plant Selection & 28 & 32 & $46.67 \%$ \\
\hline Orientation of green wall & 42 & 8 & $70 \%$ \\
\hline
\end{tabular}

As presented in table (2) $78.33 \%$ of the citizens agreed on utilizing green wall .All of the citizens agreed that green walls provide aesthetic influences. Moreover $85 \%$ of the citizens admitted the green walls has a great influence on promoting human health since by adding green walls in Cairo is one of the significant methods for reducing the percentage of carbon monoxide, carbon dioxide and other poisonous gases .

On the other side, only $20 \%$ of the citizens admitted that green walls reduce energy consumption and noise. In addition, $46.67 \%$ of the citizens were aware of the types of the plants that should be selected. According to the financial perspective, $53.33 \%$ of the citizens agreed that green walls will cost a considerable maintenance expenses. Some citizens had concerns with presence of insects, maintenance expenses, survival of plants and continuous care which green wall needed.

B. Architects' opinions About the Vertical Garden as a sustainable urban Perspective. 
JES, Assiut University, Faculty of Engineering, Vol. 46, No. 2, March 2018, pp.246-262

Table 3.

Descriptive Analysis of the Importance of Main Design Considerations for Vertical Garden [Source - Researcher]

\begin{tabular}{|l|c|c|c|}
\hline \multicolumn{1}{|c|}{ the main design considerations } & Mean \% & Std. Deviation & Frequency\% \\
\hline Architectural Considerations & 25.93 & 4.072707 & 21.42 \\
\hline Construction Considerations & 29.95 & 8.66041 & 21.25 \\
\hline Economical Considerations & 14.76 & 6.18802 & 56.98 \\
\hline Environmental Considerations & 29.36 & 8.74690 & 52.3 \\
\hline
\end{tabular}

As presented in table (3) the highest percentage of the main design considerations was construction considerations $29.95 \%$ which indicated that structural integrity of the building must be verified prior to consideration of retrofitting the building with a green wall. The environmental considerations were the second rank and the architectural considerations were at the third.

Table 4.

Descriptive analysis \& Component Analysis of The Importance of Design Considerations for Vertical Garden [Source - Researcher]

\begin{tabular}{|c|c|c|c|c|c|}
\hline \multirow{2}{*}{$\begin{array}{c}\text { Design considerations for vertical } \\
\text { garden }\end{array}$} & \multicolumn{3}{|c|}{ Descriptive analysis } & \multicolumn{2}{|c|}{$\begin{array}{l}\text { Component } \\
\text { analysis }\end{array}$} \\
\hline & Mean\% & $\begin{array}{c}\text { Std. } \\
\text { Deviation }\end{array}$ & Variance & 1 & 2 \\
\hline \multicolumn{6}{|l|}{ Architectural Considerations } \\
\hline Vertical garden types & 14.44 & 1.2087 & 1.227 & .895 & .378 \\
\hline Location of façade & 12.84 & 1.6576 & 1.278 & .606 & .296 \\
\hline $\begin{array}{l}\text { Green wall is compatible with } \\
\text { building design }\end{array}$ & 13.78 & 1.2292 & 1.379 & 0.867 & 0.578 \\
\hline Aesthetic and urban design & 13 & 1.1741 & 2.7658 & 0.850 & 0.073 \\
\hline $\begin{array}{l}\text { Native plant material which } \\
\text { adaptable to local weather conditions }\end{array}$ & 12.01 & .98821 & 1.573 & .737 & $-.096-$ \\
\hline Determining a plant's hardiness & 11.16 & .8346 & 1.374 & .561 & .381 \\
\hline Facade surface area & 11.17 & 1.2735 & 1.182 & .509 & $-.122-$ \\
\hline Plant material selection & 11.6 & 1.3773 & 1.817 & .575 & .041 \\
\hline \multicolumn{6}{|l|}{ Construction Considerations } \\
\hline $\begin{array}{l}\text { Green wall is compatible with the } \\
\text { type of construction }\end{array}$ & 25.3 & 2.3992 & 1.676 & .887 & $-.008-$ \\
\hline Protection to building structure & 17.07 & 1.6594 & 1.226 & .679 & .089 \\
\hline Utilizing grey water technology & 13.13 & 1.7800 & 1.883 & .439 & .663 \\
\hline $\begin{array}{l}\text { Availability of drainage system and } \\
\text { water proofing }\end{array}$ & 23.1 & 2.8316 & 2.701 & .826 & $-.272-$ \\
\hline Irrigation availability & 21.4 & 2.0150 & 1.559 & .721 & $-.114-$ \\
\hline \multicolumn{6}{|l|}{ Economic Considerations } \\
\hline Irrigation installation costs. & 27.3 & 4.5522 & 1.310 & .726 & .065 \\
\hline Materials cost & 18.1 & 3.9768 & 0.612 & .474 & .676 \\
\hline $\begin{array}{l}\text { Installation of the system components, } \\
\text { plants and plant materials }\end{array}$ & 29.5 & 4.6538 & 1.501 & .761 & $-.217-$ \\
\hline Maintenance expenses & 25.1 & 2.1099 & 1.439 & .747 & $-.048-$ \\
\hline \multicolumn{6}{|l|}{ Environmental Considerations } \\
\hline Reduced energy use \& temp. control & 12.79 & 3.8911 & 1.425 & .878 & .096 \\
\hline Noise reduction via insulation & 13.66 & 3.7125 & 1.202 & .845 & .292 \\
\hline
\end{tabular}


Table 4. (Cont.)

\begin{tabular}{|l|l|l|l|l|l|}
\hline Improved indoor air quality & 13.22 & 4.0201 & 1.377 & .867 & .184 \\
\hline Adapting to climate change & 11.91 & 3.6127 & 1.337 & .859 & $-.119-$ \\
\hline Integrate - landscape \& biodiversity & 11.92 & 3.8332 & 1.489 & .720 & $-.120-$ \\
\hline Reduce urban heat Island & 12.3 & 3.7665 & 1.494 & .835 & $-.306-$ \\
\hline Improved public health and wellbeing & 12.1 & 3.8334 & 1.356 & .756 & .385 \\
\hline planting bed/ soil preparation & 12.1 & 2.2986 & 1.442 & .787 & .389 \\
\hline
\end{tabular}

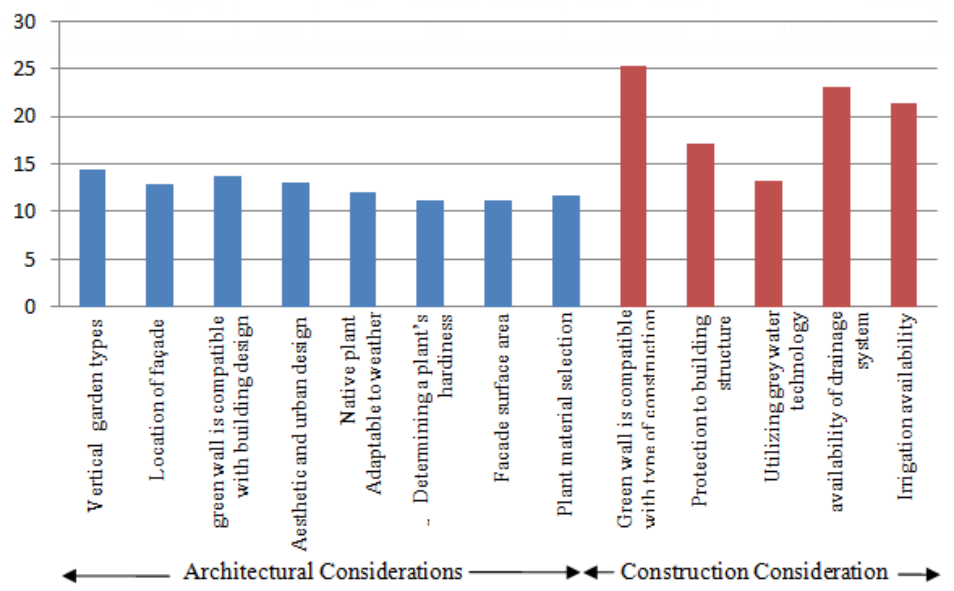

Fig. 12. Shows a Descriptive analysis (Mean) of Architectural and Construction Considerations

As presented in [Figure-12-], Most of the Architects agreed upon several architectural elements, the most important element was the vertical garden type which is chosen according to the financial budget and the constructional considerations. Moreover, there was other architectural elements for instance, green wall is compatible with building design, aesthetic and urban design and location of façade and plants selection. However, the least demanded element was determining a plant's hardiness. On the other side, there were several demanded construction considerations of vertical garden such as green wall is compatible with the type of construction, availability of drainage system and water proofing, irrigation availability and protection to building structure. However, the least importance element was utilizing grey water technology.

As shown in [Figure-13-], the most expensive elements were installation of the system components and irrigation installation. However, the lowest costs were the plant materials and maintenance expenses.

On the other side, all the variables of environmental considerations were significant and important. So, incorporation of vertical gardens with buildings is achieving expected environmental aspects. 


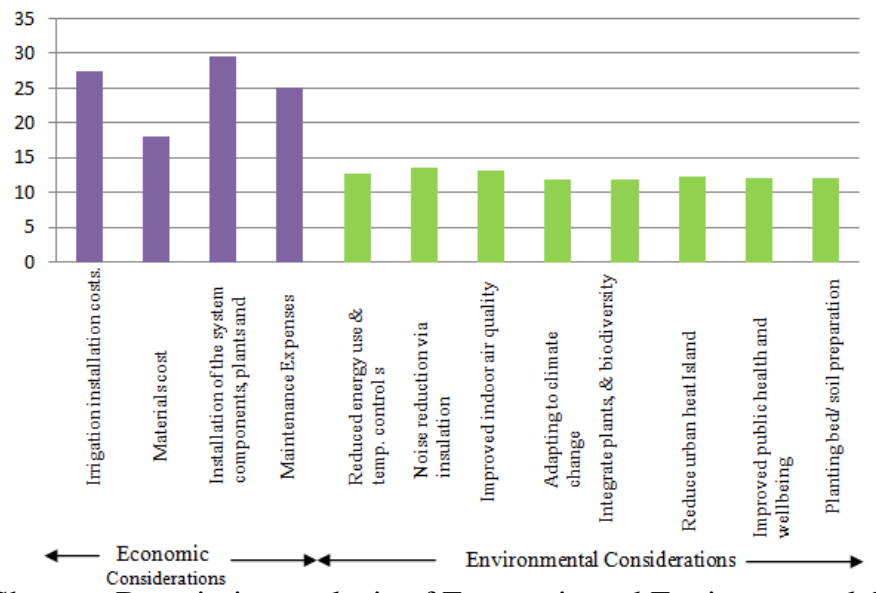

Fig. 13. Shows a Descriptive analysis of Economic and Environmental Considerations

\section{Finding and recommendation}

The paper managed to understand the citizens' perceptions and concerns about vertical garden and to outline the importance of design considerations of vertical garden according to architect's point of view, through conducting a profound theoretical and practical analysis. The paper concluded a checklist of design considerations for vertical garden which is shown in two stages:

The first stage composes of theoretical review of vertical gardens' types, its benefits and international experiments for utilizing vertical garden. The main aim of this stage is to determine the elements of design considerations of vertical garden shown in [Table -1].

The second stage, the paper depended on frequency distribution, descriptive and component Analysis of the Proposed design considerations of vertical garden, as shown in [Tables - 2 -3]. The defined variables, utilized and conducted from analytical study, that aim to provide a Relative weights checklist of design considerations for vertical garden, as shown in [Table -4 ], that can be applied on any form of green wall design in existing buildings and new ones ,Among the findings of this study are the following:

- Architectural Considerations

Architectural Considerations represent $25.93 \%$ of design Considerations, Which utilizing to retrofit the building with a vertical garden through, choosing Suitable vertical garden's type with the building [3.74\%] Green wall is compatible with building design [3.35\% ],Location of utilized green façade [3.33\%] , plant material is commensurate with local climatic conditions [3.1\%], native plant material $(3.11 \%)$ and determining utilized plants' hardiness [2.98\%] .

Aesthetic and urban design represent $3.37 \%$ of architectural considerations through Adding more green spaces in the city might prove to be one of the more effective ways of coming to grips with urban changes. It is clear that urban green spaces are about more than just recreation and visual appeal.

According to citizens' perceptions, vertical gardens an increasingly important factor in making cities of tomorrow more livable By bringing nature to buildings. Additionally vertical gardens can help to address the lack of green spaces in Cairo city . 
- Construction Considerations

Construction Considerations represented $29.95 \%$ of design Considerations. The green wall is compatible with the type of construction was represented $7.58 \%$ of Construction Considerations and Protection to building structure[4.35\%] which must be verified prior to consideration of retrofitting the building with a green wall. Architects and landscape engineers must consider in Availability of water system which was represented $6.41 \%$ of Construction Considerations and also, Possibility to use grey water technology [3.93\%].

\section{- Economic Considerations}

Economic considerations were represented $14.76 \%$ of design considerations that were achieved through Availability of material for maintenance [3.7\%], suitable Prices of irrigation installation [4.03\%], installation of the system components [4.35\%], plants and suitable prices of plant materials [2.67\% ].

According to citizens' perceptions and concerns, the most significant concern is an economic factor. Their concerns were maintenance expenses, plants prices and installation of vertical garden on building.

On the other side, The architects found solution for these weak points like encouraging the companies and institutes which aiming to achieve sustainability to execute the maintenance of green walls and set up green walls on buildings.

Table 4.

Relative weights' checklist of design considerations for vertical garden [source- researcher]

\begin{tabular}{|c|c|c|}
\hline \multirow[t]{2}{*}{ Design Considerations for vertical garden } & \multicolumn{2}{|c|}{$\begin{array}{c}\text { Relative weights of design } \\
\text { considerations for vertical } \\
\text { garden }\end{array}$} \\
\hline & Main & Variables \\
\hline \multicolumn{3}{|l|}{ Architectural Considerations } \\
\hline Vertical garden types & \multirow{8}{*}{25.93} & 3.74 \\
\hline Location of utilized green façade & & 3.33 \\
\hline Green wall is compatible with building design & & 3.57 \\
\hline Aesthetic and urban design & & 3.37 \\
\hline Native plant material which adaptable to local & & 3.11 \\
\hline Determining a plant's hardiness & & 2.89 \\
\hline Facade surface area & & 2.9 \\
\hline Plant material selection & & 3.01 \\
\hline \multicolumn{3}{|l|}{ Construction Considerations } \\
\hline Green wall is compatible with the type of & \multirow{5}{*}{29.95} & 7.58 \\
\hline Protection to building structure & & 5.11 \\
\hline Utilizing grey water technology & & 3.93 \\
\hline Availability of drainage system \& water proofing & & 6.92 \\
\hline Irrigation availability & & 6.41 \\
\hline \multicolumn{3}{|l|}{ Economical Considerations } \\
\hline Irrigation installation costs. & \multirow{4}{*}{14.76} & 4.03 \\
\hline Materials cost & & 2.67 \\
\hline Installation of the system components, plants & & 4.35 \\
\hline Maintenance expenses & & 3.7 \\
\hline \multicolumn{3}{|l|}{ Environmental Considerations } \\
\hline Reduced energy use \& temp. control & \multirow{8}{*}{29.36} & 3.76 \\
\hline Noise reduction via insulation & & 4.3 \\
\hline Improved indoor air quality & & 3.88 \\
\hline Adapting to climate change & & 3.5 \\
\hline Integrate - landscape \& biodiversity & & 2.62 \\
\hline Reduce urban heat Island & & 3.9 \\
\hline Improved public health and wellbeing & & 3.85 \\
\hline Planting bed/soil preparation & & 3.55 \\
\hline
\end{tabular}


- Environmental Considerations

The main focus of environmental concept is utilizing green wall for cooling, refreshing the indoor environment and helping decrease the heat gain from the outdoor, thus reduce the use of energy. And make buildings biologically lively, through incorporate nature with buildings.

Obviously, incorporation of vertical gardens with buildings are achieving expected environmental aspects like, increasing energy efficiency, reducing the urban heat island effect, noise reductions and providing air quality. Furthermore, vertical gardens have aesthetic, physiological and psychological benefits which promote human health, wellbeing and satisfaction

Certainly, adding more vertical gardens in Cairo specially new cities are beyond visual interest But, they are one of the most successful methods for grasping the lack of green spaces, improving the environmental aspects, public health and achieving sustainable urban context. So utilizing of vertical gardens are an inexorable vital factor to make urban areas in Cairo more livable.

\section{REFERENCES}

[1] Isnin, Z., Ahmad, S. S., \& Yahya, Z. (2012). Challenges of the unknown building material substances for greener adaptation projects. Procedia- Social and Behavioral Sciences, 68, :53-62.

[2] Hunter, A. M., et al. (2014). Quantifying the thermal performance of green facades: A critical review. Ecological Engineering, 63: 102-113.

[3] Krushe P, Krushe M, Althaus D, Gabriel I.(1982) Okologisches Bauen Herausgegeben vom Umweltbundesamt. Wiesbaden und Berlin: Bauverlag.

[4] Wood, A., Bahrami, P., \& Safarik, D. (2014). Green walls in high-rise buildings: An output of the CTBUH sustainability working group. Images Publishing.

[5] Marwa H.(2015).Green Facades, International Journal of Science and Technology, V. 2 ( 1), : 325-340

[6] Newton J, Gedge D, Early P, Wilson S.( 2007). Building greener guidance on the use of green roofs, green walls and complementary features on buildings. London, UK: CIRIA.

[7] Green Roof Organization (2008). Introduction to Green Walls Technology, Benefits \& Design.

[8] Lauren J. Paricio I. Alvarez J. Ruiz F. (2005). Natural envelope. the green element as a boundary limit. SB05Tokyo. The world Sustainable Building Conference, Tokyo.

[9]https://greenscreen.com/docs/Education/greenscreen_Introduction\%20to\%20Green\%20Walls. pdf

[10] Yeh Y.P. (2012). Green Wall-The Creative Solution in Response to the Urban Heat Island Effect. National Chung-Hsing University

[11] Ottele M., Pernni K. Fraaij A. Haas E. Raiteri R.(2011) Comarative life cycle analysis for green facades and living a11 systems. Energy Build: 3419-29.

[12] Othman A., Sahidin N. ( 2015). Vertical Greening C as Passive Approach in Sustainable Design. AMER International Conference on Quality of Life, Jakarta, Indonesia: 25-27

[13] Jonathan, A. (2003) Vegetation Climate Interaction : How Vegetation Makes the Global Environment. New York: Springer.

[14]https://www.murvegetalpatrickblanc.com/realisations/paris-ile-de-france/musee-du-quaibranly

[15] Odum, H.T., (1995). Scales of ecological engineering. Ecol. Eng. 6 (1996), 7 19. Pekkanen J, Timonen KL, Tiittanen P, Vallius M, Lanki T, Sinkko H.( 2000). Exposure and Risk Assessment for Fine and Ultrafine Particles in Ambient Air. National Public Health Institute.

[16] Caplow, T. et al.(2008) Vertically Integrated Greenhouse: Realizing the

Ecological Benefits of Urban Food Production, Proceeding of The Eco-city 
World Summit, San Francesco, USA.

[17] Pérez G. , Julia c., salvador S. ,Luisa F.(2017). Green facade for energy savings in buildings: The influence of leaf area index and facade orientation on the shadow effect , Applied Energy , V.187:.424-437

[18] Green over Grey - Living Walls and Design, www.greenovergrey.com

[19] www.greenroofs.org/index.php/about-green-roofs/green-roof-benefits

[20] Azkorra Z . ,. Pérez G, Coma J., Cabeza L.F., Bures S., lvaro J.E., Erkoreka A. , Urrestarazu M.(2015). Evaluation of green walls as a passive acoustic insulation system for buildings , Applied Acoustics, v.89: 46-56.

[21] N.H. Wong, A.Y.K. Tan, P.Y. Tan, K. Chiang, N.C. (2010).Wong Acoustics evaluation of vertical greenery systems for building walls Build Environ, 45:411-420

[22]Wong N.H. , Kwang Tan A. Chen Y., Sekar K., Tan P.Y., Chan D., Chiang K., Wong N.C. (2010). Thermal Evaluation of Vertical Greenery Systems for Building Walls," Building and Environment 45(3):663-672.

[23] Ko“hler M. (2008). Green Facades-A View Back and some Visions. Urban Ecosystems: $423-436$.

[24] Elinc Z.K. , Kaya L.C., Danac1 H.M., Baktir I., Go"ktu“ rk R.S., (2013) .Use of Outdoor Living Walls in Mediterranean- like Climates: A Case Study of Antalya Kaleic,i,” Journal of Food, Agriculture \& Environment 11: 1 687-692

[25] Kaplan R., Kaplan S., Brown T. (1989) .Environmental Preference: A Comparison of Four Domains of Predictors. Environment and Behavior 21 , 509-530.

[26] Van den Berg A.E., Hartig T., Staats H.. (2007) .Preference for Nature in Urbanized Societies: Stress, Restoration, and the Pursuit of Sustainability. Journal of Social Issues 63, : 179-196.

[27] White E., Gatersleben B., (2011) .Greenery on Residential Buildings: Does it Affect Preferences and Perceptions of Beauty? Journal of Environmental Psychology 31: 1, 89-98.

[28] Ulrich R.S. (1984). View through a window may influence recovery from surgery. Journal of Science. 224,420-421.

[29] Kuo F.E., Sullivan W.C. (2001). Environment and crime in the inner city - Does vegetation reduce crime?. Environment and Behavior, 33 (3), 343-367.

[30] Johnston J., Newton J. (1996). Building Green: A Guide for Using Plants on Roofs, Walls and Pavements. London: The London Ecology Unit.

[31] Wilmers F. (1997). Effects of vegetation on urban climate and buildings. Energy and Buildings, 15-16, 507-514.

[32] Despommier D. (2009) .The Rise of Vertical Farms, Scientific American 301 (5), : 80-87.

[33] Despommier D., (2011) .The Vertical Farm: Controlled Environment Agriculture Carried Out in Tall Buildings Would Create Greater Food Safety and Security for Large Urban Populations. Journal fu" r Verbraucherschutz und Lebensmittelsicherheit 6( 2), :233-236.

[34] Abel C. (2010) .The Vertical Garden City: Towards a New Urban Topology. Council on Tall Buildings and Urban Habitat Journal 2, 20-30.

[35] Pastorelli, Giuliano, (2009), Plata form an Arquitectura, Web Article, Posted in: Architecture Office, Landscaping. Retrieved on January 19, 2018, from https://www.plataformaarquitectura.cl/cl/02-14392/edificio-consorcio-sede-santiago-enriquebrowne-borja-huidobro

[36] Afrin S. (2009). Green Skyscraper: Integration of Plants into Skyscrapers. KTH, Department of Urban Planning and Environment Division of Urban and Regional Studies, Stockholm.

[37] Edith Green - Wendell Wyatt Federal Building Modernization, Energy Analysis Report (2013). Energy Performance, V. 7.0, retrieved on January 19, 2018, from http://www.aiatopten.org/sites/default/files/EGWW\%20Energy\%20Report.pdf

[38] Shepherd L. (2015).A Model Modernization: Edith Green-Wendell Wyatt Federal Building, And GSA Mid century Inventory, CTBUH, New York Conference.

[39] Yeang, ken, (2006). Eco-design: A Manual for Ecological Design, Wiley Academy, Great Britain. ISBN 0-470-85291-7 


\section{الحديقة الراسية كمنظور عمراني مستدام في القاهرة}

$$
\text { الملخص العربى }
$$

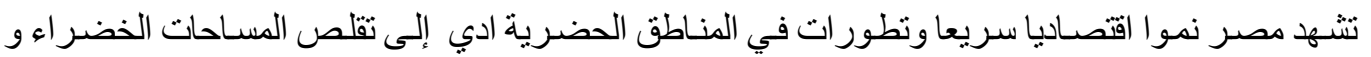

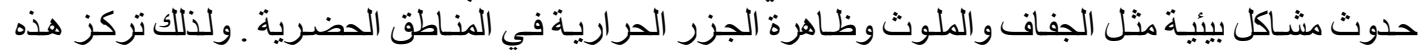

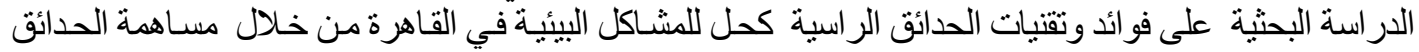

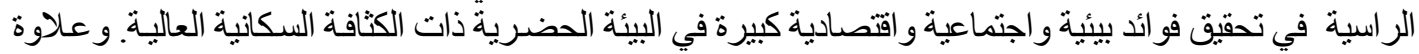

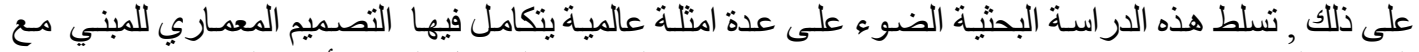
الحدائق الر اسية باعتبار ها منظور معماري و عمر اني مستدام لمواجهة المشاكل البيئية وأزمة الطاقة.

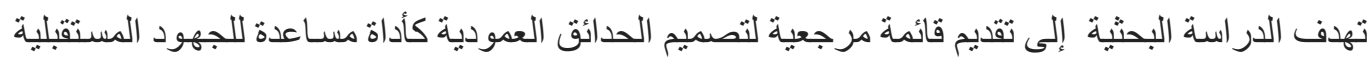

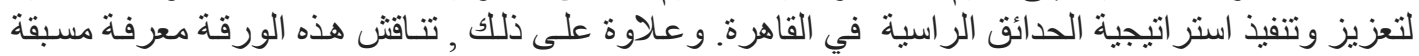

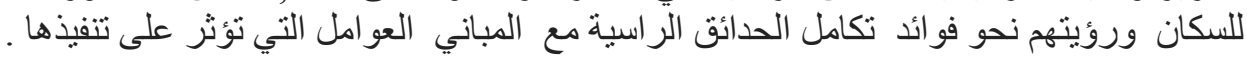
و أخيرا , تختتم الدراسة البحثية بقائمة مرجعية ذات اوزان نسبية للاعتبار ات التصميم للحدائق الر اسية

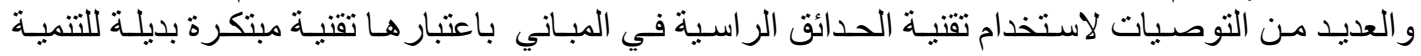

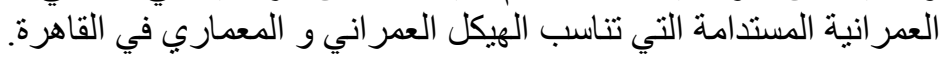
الكلمات المفتاحيةّ: حديقة الر اسية , الجدار الأخضر , الواجهة الخضر اء, أنظمة الحليقة الراسية , توفير الطاقة. 